\title{
SCG10, a Microtubule-Destabilizing Factor, Interacts Directly with Kinesin Superfamily KIF1A Protein in Brain
}

\author{
॥ Soo Moon ${ }^{1}$ and Dae-Hyun Seog* \\ Departments of Biochemistry, College of Medicine, Inje University, Busan 614-735, Korea \\ ${ }^{1}$ Departments of Anatomy, College of Medicine, Dongguk University, Gyeongiu, Korea
}

Received April 17, 2009 / Accepted April 28, 2009

\begin{abstract}
Microtubules, a major cytoskeleton, form parallel arrays in the axon and are oriented with their plus ends toward the cell periphery. Kinesin superfamily proteins (KIFs) are the molecular motors acting in the microtubule-based motilities of organelles in cells. Here, we used the yeast two-hybrid system to identify the protein that interacts with the coiled-coil domain of KIF1A and found a specific interaction with microtubule-destabilizing factor SCG10. SCG10 bound to the amino acid residues between 400 and 820 of KIF1A, but not to other KIFs in the yeast two-hybrid assay. The coiled-coil domain of SCG10 is essential for interaction with KIF1A. In addition, this specific interaction was also observed in the Glutathione $S$-transferase pull-down assay. An antibody to SCG10 specifically co-immunoprecipitated KIF1A associated with SCG10 from mouse brain extracts. These results suggest that KIF1A motor protein transports SCG10-containing vesicles along microtubules in neurons.
\end{abstract}

Key words : Kinesin, SCG10, molecular motors, microtubule, binding protein

\section{Introduction}

Appropriate localization of sub-cellular elements are necessary to normal cellular function. For example, proteins synthesized in the cell body of neurons must be transported to the axon terminal where they function $[19,20]$. An important component of neuronal cytoskeleton is the microtubules [3,18]. They act as tracks for organelle transport $[12,20]$. In neurons, axonal microtubules are organized such that the plus ends face towards the axon terminal while the minus ends face towards the cell body $[3,4,18]$. Kinesin superfamily proteins (KIFs) are the molecular motors conveying vesicles along microtubules $[1,22,40]$. Anterograde axonal transport has been shown to depend on members of the KIFs, which transport organelles, protein complexes, and mRNAs to specific destinations in ATP-dependent manner $[24,46,50]$. Defects in axonal transport have been observed commonly in neurodegenerative disease [16,21,48,49]. For example, amyloid precursor protein (APP) is a receptor for conventional kinesin. Impairment of axonal transport, due to APP mutation, plays a causative role in Alzheimer's disease [13]. Mutations in neuronal kinesin genes recently have been linked to human neurodegenerative disease, most likely as the consequence of impaired axonal transport [52,35].

*Corresponding author

Tel : +82-51-890-6974, Fax : +82-51-894-5801

E-mail : daehyun@inje.ac.kr
Within KIFs, the KIF1 subgroup comprises N-type motor proteins classified as fast anterograde plus-end-directed motor protein. Kif1 genes are subdivided into KiflA, KiflB, Kif1B $\beta$, KiflC and Kif1D which responsible for the transport of cargoes [10,11,30,32]. Knockout of Kifla gene was lethal in mice in the perinatal periods, and the number of synaptic vesicles was significantly reduced [31]. Unc-104, a homologue of KIF1A in Caenorhabditis elegans, is also required for the transport of synaptic vesicle precursors $[17,26]$. KIF1A has a motor domain that interacts with the microtubule track and hydrolyzes ATP. Carboxy-terminal region of KIF1A is comprised of three functional domains: a coiled-coil domain (420-800), a stalk domain (764-1603), and a Pleckstrin homology $(\mathrm{PH})[1,32]$.

Previous study suggested that the coiled-coil domain is required for cargo transport by binding proteins that have not been identified $[17,26,31]$. In addition, little is known about the mechanism for cargo recognition and transport regulation, such as control of cargo loading and unloading. In this study, using the yeast two-hybrid screens, we identified SCG10 as a protein that interacts with KIF1A in vitro and in vivo.

\section{Materials and Methods}

\section{Plasmid constructs}

A previously described mouse SCG10 cDNA [33,43] was 
cloned into T-vector (Invitrogen, Carlsbad, CA, USA) using by reverse transcriptase polymerase chain reaction (RT-PCR). After EcolI digestion, the SCG10 was inserted into the EcoKI site of pB42AD (Clontech, Palo Alto, CA, USA). cDNA of KIF1A [32] was utilized as a template to amplify the region coding for amino acids (a.a) 420-820 using appropriate primers. The amplified fragment was sub-cloned into T-vector. The fragment was then EcokI-digested and sub-cloned into the EcoKI site of pLexA. The correct orientation of the cDNA inserts was verified by restriction enzyme analysis, and sequence analysis was used to check that they were in-frame. Other molecular procedures were performed according to the standard protocols [37].

\section{Screening of KIF1A-binding proteins by the yeast two-hybrid assay}

The Matchmaker LexA two-hybrid system was used for screening according to the manufacturer's manual (Clontech). In brief, a part of the kif1a gene ([aa] 420-820) was fused to the DNA-BD region of the pLexA vector, and the plasmid DNA was transformed into yeast strain EGY48 carrying the p8op-lacZ gene. Transformed EGY48 yeast strains containing the KIF1A bait plasmid were transformed with a mouse brain cDNA library $[25,39]$ and the cells were grown on synthetic dextrose (SD) plates supplemented with glucose but with no histidine, tryptophan, or uracil (SD/-His/-Trp/-Ura). The selection of positive clones was performed on an SD/-His/-Trp/-Ura/-Leu plate containing galactose, raffinose, and X-gal. Library plasmids from positive colonies were isolated and rescued using E. coli strain (KC8 strain) on ampicillin-resistant plates. Library inserts were then amplified by PCR and analyzed by restriction enzyme digestion. Unique inserts were sequenced, and DNA and protein sequence analysis were performed with the BLAST algorithm at the National Center for Biotechnology Information (NCBI). After isolation of the plasmids encoding the library clones, these plasmids were tested for interactions of the reporter gene in yeast by the retransformation. Activation of the reporter genes in the positive colonies was confirmed in the same experiments.

Cell fractionation, co-immunoprecipitation and Western blot analysis

Cell fractionation was performed using a modified version of the protocol described by Okada et al. [32]. In brief, one mouse brain was homogenized on ice with a glass homogenizer in $3 \mathrm{ml}$ of homogenization buffer ( $0.32 \mathrm{M}$ sucrose,
4 mM HEPES, pH 7.3) supplemented with protease inhibitors. The homogenate was clarified by centrifugation at $900 \times g$ for $10 \mathrm{~min}$ followed by centrifugation at $1,000 \times$ $g$ for $10 \mathrm{~min}$, producing a pellet (P1) and supernatant (S1). The S1 supernatant was centrifuged again at $12,000 \times g$ for $15 \mathrm{~min}$, and the resulting supernatant (S2) was saved. Protein concentrations were determined using the Bio-Rad DC protein assay kit. For immunoprecipitation of the S2 fraction, the samples were diluted in the same volume of $2 \mathrm{X}$ binding buffer (50 mM HEPES, $240 \mathrm{mM} \mathrm{KCl}, 2 \mathrm{mg} / \mathrm{ml} \mathrm{BSA}$, $0.2 \%$ Triton X-100, pH 7.4) and incubated overnight with an anti-SCG10 antibody (Santa Cruz biotechnology, Santa Cruz, CA, USA) or with control $\mathrm{IgG}$ overnight at $4^{\circ} \mathrm{C}$, followed by precipitation with protein-A Sepharose (Amersham Pharmacia, Piscataway, NJ, USA). The beads were collected by brief centrifugation and washed three times with TBS-T (20 mM Tris-HCl, pH 7.5, $0.15 \mathrm{M} \mathrm{NaCl}, 0.1 \%$ tween 20 ). The pellets were eluted and denatured by boiling for $2 \mathrm{~min}$ in Laemmli's loading buffer and then resolved by sodium dodecyl sulphate (SDS)-PAGE. The gel was transferred to a nitrocellulose membrane and incubated with antibodies against the KIF1A [32], KIF1B $\beta$ [52], KIF5B [23] and KIF17 [41]. Rabbit horseradish-linked secondary antibody (Sigma-Aldrich, St. Louis, MO, USA) was used at a final dilution of 1:2,000, and inmmunoreactivities were detected using the ECL Western blotting system.

Glutathione S-transferase (GST) pull-down assays

Pull-down assays using GST fusion proteins were performed as follows. cDNAs encoding the domains of SCG10 were cloned in pET41, and the recombinant GST-SCG10 fusion proteins were expressed in bacterial strain BL21 GOLD (Stratagene, La Jolla, CA, USA) after induction with $1 \mathrm{mM}$ isopropyl thio- $\beta$-D-galactopyranoside (Fisher Biotech, South Australia, Australia). The fusion proteins were purified using glutathione-agarose beads (Sigma-Aldrich, St. Louis, MO, USA) according to the manufacturer's protocol. GST alone or GST fusion proteins were dialyzed for $2 \mathrm{hr}$ in PBS using Slide-A-Lyzer (Pierce, Rockford, IL, USA). Ten $\mu \mathrm{g}$ of each of the GST fusion proteins was then coupled to $50 \mu \mathrm{l}$ of glutathione-agarose beads for each reaction by incubating at room temperature for $1 \mathrm{hr}$, followed by rinsing several times with PBS. The mouse brain S2 fraction was incubated overnight at $4^{\circ} \mathrm{C}$ with the GST fusion protein-coupled glutathione beads. The beads were pelleted by centrifugation, washed three times with the extraction buffer $(1 \%$ Triton $\mathrm{X}-100$ in PBS containing $10 \mu \mathrm{g} / \mathrm{ml}$ each aprotinin, leupeptin, 
and pepstatin and $1 \mu \mathrm{M}$ phenylmethanesulfonyl fluoride), and once with PBS. The bound proteins were eluted from the glutathione beads with $100 \mu$ of SDS sample buffer. The samples were boiled for $5 \mathrm{~min}$ and then processed for SDS-PAGE and Western blotting with antibodies to KIF1A.

\section{Results}

Identification of $\mathrm{KIF1A}$ interacting proteins by yeast two-hybrid screening

Recent studies have suggested that the $\mathrm{PH}$ domain of KIF1A is insufficient to bind and transport vesicles in vivo, and that unidentified proteins that bind to the coiled-coil domain of KIF1A are required [46,31]. Using coiled-coil domain (420-820 aa) as a bait, we identified eleven potential binding partners by screening $5 \times 10^{6}$ independent mouse brain pB42AD-cDNA colonies. Plasmid DNAs encoding putative interactors were isolated from the positive clones. These clones were individually isolated, sequenced and subjected to further yeast two-hybrid filter assay to confirm the interactions. We obtained three positive clones which were turned out to be cDNA full length and fragments containing SCG10 (Fig. 1A). The three positive SCG10 clones (clones 2,3 and 6) overlapped at the open reading frame (ORF) of
SCG10 (Fig. 1A). We did not analyze further the rest eight clones which encoded unknown proteins. To identify the region of KIF1A required for the interaction with SCG10, we constructed deletion mutants of KIF1A and analyzed their interactions with SCG10 using the yeast two-hybrid assay (Fig. 1B). This experiment demonstrated that the minimal binding domain was located in a small region of KIF1A corresponding to amino acids 400-820. SCG10 contains three functional domains: membrane anchoring (MA), regulatory, and coiled-coil domains [15,31]. To identify the region of SCG10 required for the interaction with KIF1A, we constructed deletion mutants of SCG10 and analyzed their interactions with KIF1A using the yeast two-hybrid assay. MA domain and regulatory domain did not bind KIF1A. The coiled-coil domain of SCG10 interacted with KIF1A in the yeast two-hybrid assay (Fig. 1C). These results indicate that the binding domain was located in the coiled-coil domain of SCG10 corresponding to amino acids 78-179.

To clarify whether SCG10 interacts specifically with KIF1A or whether the interaction includes other isoforms of KIF1A, the tails of KIF1A, KIF1B, KIF1C, KIF3B, KIF5B and KIF17 were tested for binding with SCG10 (Fig. 2). There was no detectable binding between SCG10 and the tail domains of the other major neuronal KIF, such as KIF17. The

(A)

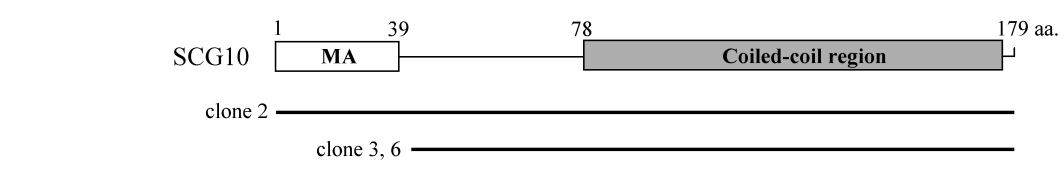

(B)

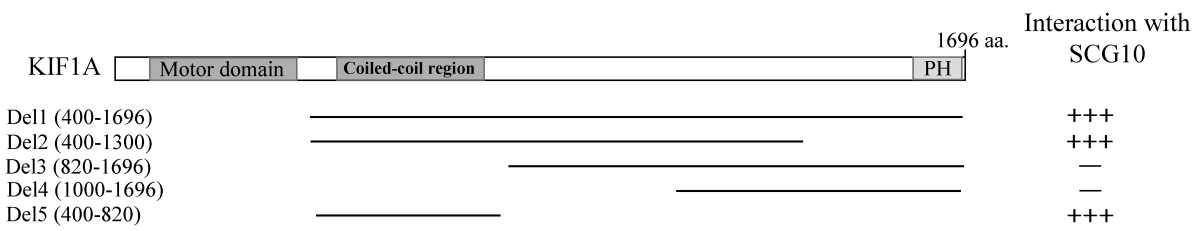

(C)

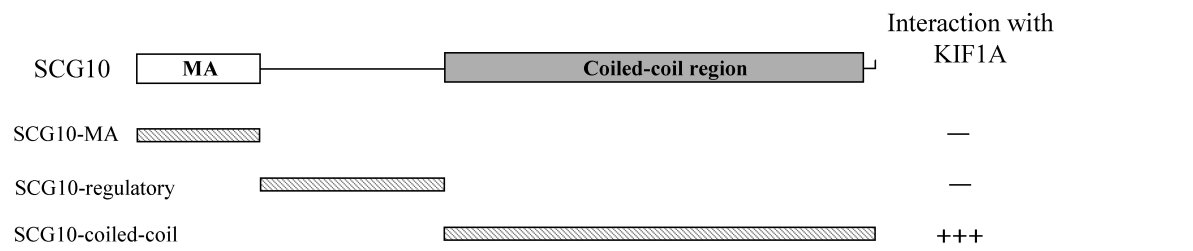

Fig. 1. Identification of the proteins interacting with KIF1A by yeast two-hybrid screening. (A) Schematic diagram of domain structure of SCG10. The open box corresponds to MA domain and the filled box to the coiled-coil domain. Clone 2, 3 and 6 were overlapped at the open reading frame (ORF) of SCG10. aa, the amino acid residue number. (B) Minimal SCG10 binding region in KIF1A. Motor domain is indicated in gray. Truncated KIF1As were constructed by PCR. Several truncated forms of KIF1A were tested in the yeast two-hybrid assay for interaction with SCG10. Amino acid numbers are indicated on the left. +, interaction with SCG10 -, no interaction with SCG10. aa, the amino acid residue number. (C) Schematic representation of the SCG10 truncation clones. Several truncated forms of SCG10 were tested in the yeast two-hybrid assay for interaction with KIF1A. +, interaction with KIF1A; -, no interaction with KIF1A. 


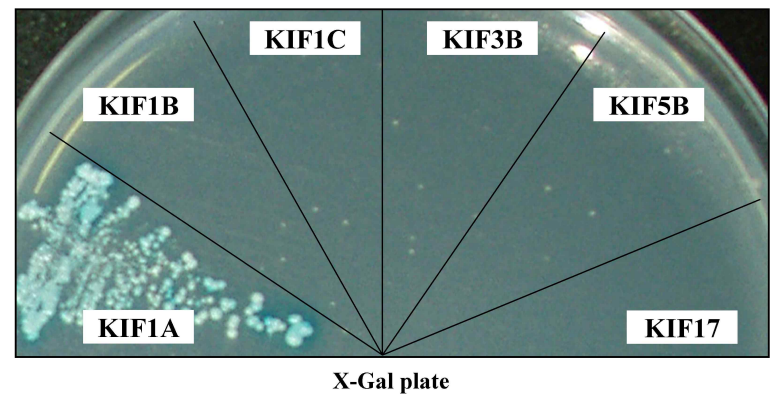

Fig. 2. Interaction between KIFs and SCG10. The C-terminal regions of each KIF protein were fused to the pLexA DNA binding domain. SCG10 specifically interacted with KIF1A but not with KIF1B, KIF1C, KIF3B, KIF5B, or KIF17.

ubiquitous KIFs, such as KIF1B, KIF1C, KIF3B and KIF5B also did not bind SCG10. These data indicate that SCG10 binds specifically to KIF1A.

SCG10 is associated with KIF1A at the protein level As an additional demonstration for interaction between KIF1A and SCG10, we employed GST pull-down experiments. Recombinant GST-SCG10-MA/regulatory, GST-SCG10-coiled-coil or GST-SCG10-full length fusion proteins were expressed in E. coli. The purified GST fusion proteins are allowed to interact with mouse brain extracts. Western blot analyses revealed that KIF1A interacted with GST-SCG10-coiled-coil, but not with GST-SCG10-MA/regulatory, consistent with the yeast two-hybrid assay results (Fig. 3A). However, SCG10 MA domain and regulatory domain did not interact with KIF1A (Fig. 3A), as expected on the basis of yeast two-hybrid assay result. These results suggest that the coiled-coil domain of SCG10 interacts with KIF1A.

In order to determine whether the interaction between SCG10 and KIF1A also takes place in vivo, we performed co-immunoprecipitation experiments using mouse brain extracts. Lysates from mouse brain were incubated with an anti-SCG10 antibody. Protein G-agarose beads selectively precipitated the immuno-complexes, which were then subsequently separated by SDS-PAGE and immunoblotted with anti-KIFs antibodies (Fig. 3B). As shown in Fig. 3B, SCG10 was co-immunoprecipitated with KIF1A but not with KIF1B, KIF5B and KIF17, which are consistent with the result from yeast two-hybrid assay. These results indicate that SCG10 is a specific binding partner of KIF1A in vivo. Taken together, our data show that KIF1A and SCG10 specifically interact in vivo.
(A)

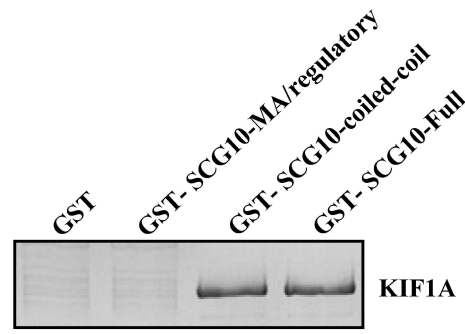

(B)

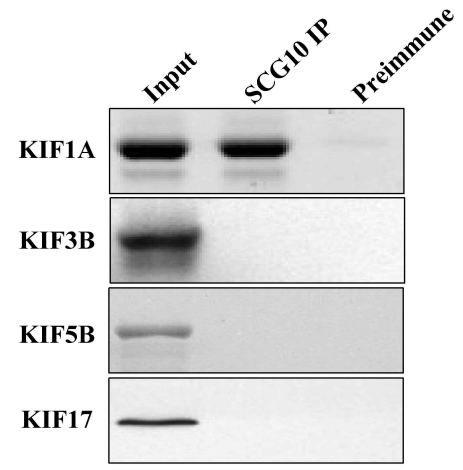

Fig. 3. Association of KIF1A with SCG10 in the GST pull-down assay and co-immunoprecipitation. (A) Proteins in the mouse brain lysate were allowed to bind to GST alone, GST-SCG10-MA/regulatory, GST-SCG10-coiled-coil and GST-SCG10 fusion proteins. The elution fractions were resolved by SDS-PAGE, and Western blotting was performed using an antibody to KIF1A. (B) Mouse brain lysates were immunoprecipitated with an anti-SCG10 antibody or preimmune serum, and the precipitates were immunoblotted with anti-KIF antibodies. Input: $10 \%$ of the mouse brain lysates used for each co-immunoprecipitation assay.

\section{Discussion}

Here we described the interaction of KIF1A with SCG10. Using a combination of yeast two-hybrid analysis, in vitro and in vivo association assays, we obtained evidence that KIF1A interacts directly with SCG10, a neuronal homologue of stathmin. The findings of our study provide evidence that SCG10 is a candidate molecule receptor of KIF1A. Therefore, it is tempting to speculate that KIF1A-SCG10 interaction is important for the transport of microtubule destabilizing complexes.

The dynamic state of microtubules has been shown to be important for axon outgrowth, guidance, and branching $[7,14,42]$. Microtubules form dense parallel arrays in the axon shaft and are oriented with their plus ends toward the growth cone [3,18]. All members of the stathmin family destabilize microtubules by sequestering tubulin through their conserved stathmin-like domain [5,36]. Members of the 
stathmin family are involved in neurite extension and axon guidance $[15,36]$. Stathmin knockout mice exhibit deficits in long-term potentiation, supporting a role of stathmin in modulating the structure of synapse [38,51]. In addition, an increased amount of polymerized tubulin was detected in the neuronal cell of these mutants [38].

SCG10, a neuron-specific isoform of stathmin, is expressed predominantly in developing neurons [33,42]. SCG10 has been implicated in the regulation of neurite growth [36]. It can stabilized the plus ends by increasing the rate and extent of growth and destabilize the minus ends $[5,44]$. SCG10 is broadly expressed in the embryonic central and peripheral nervous system and is present in the growth cones of axon $[8,9,43,45]$. SCG10 is required for axon formation and extension by modulating microtubule dynamics $[8,15,27,29]$. Arriving at the destination, cargoes must be released from the KIFs before being introduced into the targeted membrane or any other destination. Previous work showed that the phosphorylation of KIF5 regulates the binding affinity of cargo vesicles [20,22]. After releasing their cargoes, motor proteins are supposed to be degraded at the destination [20]. Although the mechanism by which SCG10 releases from KIF1A is not yet clear, SCG10 has capacity to sequester tubulin dimers [7]. This may be essential for regulation of growth cone microtubules and determine growth cone advance [14].

In neuron, newly synthesized membrane proteins are sorted in the Golgi apparatus of the cell body and are then transported to axon terminal. The proposed machinery for sorting and transporting membrane proteins in neurons includes: sorting signals on the transport vesicles, specific linker molecules that bind the motors associated with the transport vesicle and specialized motors for axon $[2,20,40]$. Linking of cargo vesicles with the appropriate transport motors must occur with a high degree of specificity, to preserve organelle identity and the proper flow of transport vesicles $[12,20,46]$. Biochemical and genetic analyses suggest that there are at least two mechanisms by which motors connect with their cargoes: a direct linkage through cargo transmembrane receptors and an indirect linkage through linker molecules [2,40]. Arriving at the destination, cargoes must be released from the KIFs before being introduced into the targeted membrane or any other destination. Previous work showed that the phosphorylation of KIF5 regulates the binding affinity of cargo vesicles [20,22]. After releasing their cargoes, motor proteins are supposed to be degraded at the destination [20]. Although the mechanism by which SCG10 releases from KIF1A is not yet clear, SCG10 has capacity to sequester tubulin dimmers in axon terminal [7]. This may be essential for regulation of growth cone microtubules and determine growth cone advance [14].

Although we did not show the interaction of KIF1A with other stathmin family proteins, our observations suggest that SCG10 is a direct linker molecule with a function similar to the p150 glued in axonal transport [6], as do other known linker proteins such as Sunday driver protein (Syd) and amyloid precursor protein (APP) [12,47]. To address this issue, it would be worth to identify the SCG10 containing vesicles and co-transporting SCG10 containing vesicles and KIF1A in neurons. In this work, we have identified SCG10 is KIF1A-binding "receptor" in KIF1A-dependent anterograde transport cargoes, thus revealing a new sorting/transporting system for transport of cargo vesicle in neurons.

\section{Acknowledgement}

This work was supported by an Inje University Research Grant for 2008.

\section{References}

1. Aizawa, H., Y. Sekine, R. Takemura, Z. Zhang, M. Nangaku, and N. Hirokawa. 1992. Kinesin family in murine central nervous system. J. Cell Biol. 119, 1287-1296.

2. Almenar-Queralt, A. and L. S. Goldstein. 2001. Linkers, packages and pathways: new concepts in axonal transport. Curr. Opin. Neurobiol. 11, 550-557.

3. Baas, P. W., J. S. Deitch, M. M. Black, and G. A. Banker. 1988. Polarity orientation of microtubules in hippocampal neurons: uniformity in the axon and nonuniformity in the dendrite. Proc. Natl. Acad Sci. USA 85, 8335-8339.

4. Burton, P. R. 1988. Dendrites of mitral cell neurons contain microtubules of opposite polarity. Brain Res. 473, 107-115.

5. Cassimeris, L. 2002. The oncoprotein 18/stathmin family of microtubule destabilizers. Curr. Opin. Cell Biol. 14, 18-24.

6. Dell, K. R. 2003. Dynactin polices two-way organelle traffic. J. Cell Biol. 160, 291-293.

7. Dent, E. W. and F. B. Gertler. 2003. Cytoskeletal dynamics and transport in growth cone motility and axon guidance. Neuron 40, 209-227.

8. Di Paolo, G., R. Lutjens, A. Osen-Sand, A. Sobel, S. Catsicas, and G. Grenningloh. 1997. Differential distribution of stathmin and SCG10 in developing neurons in culture. $J$. Neurosci. Res. 50, 1000-1009.

9. Di Paolo, G., R. Lutjens, V. Pellier, S. A. Stimpson, M. H. 
Beuchat, S. Catsicas, and G. Grenningloh. 1997. Targeting of SCG10 to the area of the Golgi complex is mediated by its NH2-terminal region. J. Biol. Chem 272, 5175-5182.

10. Dorner, C., T. Ciossek, S. Muller, P. H. Moller, A. Ullrich, and R. Lammers. 1998. Characterization of KIF1C, a new kinesin-like protein involved in vesicle transport from the Golgi apparatus to the endoplasmic reticulum. J. Biol. Chem 273, 20267-20275.

11. Dorner, C., A. Ullrich, H. U. Haring, and R. Lammers. 1999. The kinesin-like motor protein KIF1C occurs in intact cells as a dimer and associates with proteins of the 14-3-3 family. J. Biol. Chem 274, 33654-33660.

12. Goldstein, L. S. and Z. Yang. 2000. Microtubule-based transport systems in neurons: the roles of kinesins and dyneins. Annu. Rev. Neurosci. 23, 39-71.

13. Goldstein, L. S. 2001. Kinesin molecular motors: transport pathways, receptors, and human disease. Proc. Natl. Acad Sci. U S A 98, 6999-7003.

14. Gordon-Weeks, P. R. 2004. Microtubules and growth cone function. J. Neurobiol. 58, 70-83.

15. Grenningloh, G., S. Soehrman, P. Bondallaz, E. Ruchti, and H. Cadas. 2004. Role of the microtubule destabilizing proteins SCG10 and stathmin in neuronal growth. J. Neurobiol. $58,60-69$.

16. Griffin, J. W. and D. F. Watson. 1988. Axonal transport in neurological disease. Ann. Neurol. 23, 3-13.

17. Hall, D. H. and E. M. Hedgecock. 1991. Kinesin-related gene unc-104 is required for axonal transport of synaptic vesicles in C. elegans. Cell 65, 837-847.

18. Heidemann, S. R., J. M. Landers, and M. A. Hamborg. 1981. Polarity orientation of axonal microtubules. J. Cell Biol. 91, 661-665.

19. Hirokawa, N. 1998. Kinesin and dynein superfamily proteins and the mechanism of organelle transport. Science 279, 519-526.

20. Hirokawa, N., and Y. Noda. 2008. Intracellular transport and kinesin superfamily proteins, KIFs: structure, function, and dynamics. Physiol. Rev. 88, 1089-1118.

21. Hurd, D. D. and W. M. Saxton. 1996. Kinesin mutations cause motor neuron disease phenotypes by disrupting fast axonal transport in Drosophila. Genetics 144, 1075-1085.

22. Kamal, A. and L. S. Goldstein. 2000. Connecting vesicle transport to the cytoskeleton. Curr. Opin. Cell Biol. 12, 503-508.

23. Kanai, Y., Y. Okada, Y. Tanaka, A. Harada, S. Terada, and N. Hirokawa. 2000. KIF5C, A novel neuronal kinesin enriched in motor neurons. J. Neurosci. 20, 6374-6384.

24. Karcher, R. L., S. W. Deacon, and V. I. Gelfand. 2002. Motor-cargo interactions: the key to transport specificity. Trends Cell Biol. 12, 21-27.

25. Kim, S. J., C. H. Lee, H. Y. Park, S. S. Yea, W. H. Jang, S. K. Lee, Y. H. Park, O. S. Cha, I. S. Moon, and D. H. Seog. 2007. JSAP1 interacts with kinesin light chain 1 through conserved binding segments. Journal of Life Science $17,889-895$.

26. Klopfenstein, D. R. and R. D. Vale. 2004. The lipid binding pleckstrin homology domain in UNC-104 kinesin is necessary for synaptic vesicle transport in Caenorhabditis elegans. Mol. Biol. Cell 15, 3729-3739.

27. Lutjens, R., M. Igarashi, V. Pellier, H. Blasey, G. Di Paolo, E. Ruchti, C. Pfulg, J. K. Staple, S. Catsicas, and G. Grenningloh. 2000. Localization and targeting of SCG10 to the trans-Golgi apparatus and growth cone vesicles. Eur. J. Neurosci. 12, 2224-2234.

28. Miki, H., M. Setou, K. Kaneshiro, and N. Hirokawa. 2001. All kinesin superfamily protein, KIF, genes in mouse and human. Proc. Natl. Acad Sci. USA 98, 7004-7011.

29. Mori, N. and H. Morii. 2002. SCG10-related neuronal growth-associated proteins in neural development, plasticity, degeneration, and aging. J. Neurosci. Res. 70, 264-273.

30. Nangaku, M., R. Sato-Yoshitake, Y. Okada, Y. Noda, R. Takemura, H. Yamazaki, and N. Hirokawa. 1994. KIF1B, a novel microtubule plus end-directed monomeric motor protein for transport of mitochondria. Cell 79, 1209-1220.

31. Niwa, S., Y. Tanaka, and N. Hirokawa. 2008. KIF1Bbetaand KIF1A-mediated axonal transport of presynaptic regulator Rab3 occurs in a GTP-dependent manner through DENN/MADD. Nat. Cell Biol. 10, 1269-1279.

32. Okada, Y., H. Yamazaki, Y. Sekine-Aizawa, and N. Hirokawa. 1995. The neuron-specific kinesin superfamily protein KIF1A is a unique monomeric motor for anterograde axonal transport of synaptic vesicle precursors. Cell $81,769-780$.

33. Okazaki, T., B. N. Yoshida, K. B. Avraham, H. Wang, C. W. Wuenschell, N. A. Jenkins, N. G. Copeland, D. J. Anderson, and N. Mori. 1993. Molecular diversity of the SCG10/stathmin gene family in the mouse. Genomics 18, 360-373.

34. Poulain, F. E. and A. Sobel. 2007. The "SCG10-LIke Protein" SCLIP is a novel regulator of axonal branching in hippocampal neurons, unlike SCG10. Mol. Cell Neurosci. 34, 137-146.

35. Reid, E., M. Kloos, A. Ashley-Koch, L. Hughes, S. Bevan, I. K. Svenson, F. L. Graham, P. C. Gaskell, A. Dearlove, M. A. Pericak-Vance, D. C. Rubinsztein, and D. A. Marchuk. 2002. A kinesin heavy chain (KIF5A) mutation in hereditary spastic paraplegia (SPG10). Am J. Hum Genet. 71, 1189-1194,

36. Riederer, B. M., V. Pellier, B. Antonsson, G. Di Paolo, S. A. Stimpson, R. Lütjens, S. Catsicas, and G. Grenningloh. 1997. Regulation of microtubule dynamics by the neuronal growth-associated protein SCG10. Proc. Natl. Acad Sci. USA 94, 741-745.

37. Sambrook, J., E. F. Fritsch, and T. Maniatis. 1989. Molecular cloning: a laboratory manual. $3^{\text {rd }}$ Edition. Cold Spring Habor Laboratory, Cold Spring Habor, New York.

38. Schubart, U. K., J. Yu, J. A. Amat, Z. Wang, M. K. Hoffmann, and W. Edelmann. 1996. Normal development of mice lacking metablastin (P19), a phosphoprotein implicated in cell cycle regulation. J. Biol. Chem 271, 1406214066.

39. Seog, D. H. and I. S. Moon. 2008. $\gamma$-Aminobutyric acid transporter 2 binds to the PDZ domain of mammalian Lin-7. 
Journal of Life Science 18, 940-946.

40. Seog, D. H., D. H. Lee, and S. K. Lee. 2004. Molecular motor proteins of the kinesin superfamily proteins (KIFs): structure, cargo and disease. J. Korean Medical Science 19, 1-7.

41. Setou, M., T. Nakagawa, D. H. Seog and N. Hirokawa. 2000. Kinesin superfamily motor protein KIF17 and mLin-10 in NMDA receptor-containing vesicle transport. Science 288, 1796-1802.

42. Stein, R., N. Mori, K. Matthews, L. C. Lo, and D. J. Anderson. 1988. The NGF-inducible SCG10 mRNA encodes a novel membrane-bound protein present in growth cones and abundant in developing neurons. Neuron 1, 463-476.

43. Stein, R., S. Orit, and D. J. Anderson. 1988. The induction of a neural-specific gene, SCG10, by nerve growth factor in PC12 cells is transcriptional, protein synthesis dependent, and glucocorticoid inhibitable. Dev. Biol. 127, 316-325.

44. Suh, L. H., S. F. Oster, S. S. Soehrman, G. Grenningloh, and D. W. Sretavan. 2004. L1/Laminin modulation of growth cone response to EphB triggers growth pauses and regulates the microtubule destabilizing protein SCG10. J. Neurosci. 24, 1976-1986.

45. Tararuk, T., N. Ostman, W. Li, B. Bjorkblom, A. Padzik, J. Zdrojewska, V. Hongisto, T. Herdegen, W. Konopka, M. J. Courtney, and E. T. Coffey. 2006. JNK1 phosphorylation of SCG10 determines microtubule dynamics and axodendritic length. J. Cell Biol. 173, 265-277.

46. Vale, R. D. 2003. The molecular motor toolbox for intra- cellular transport. Cell 112, 467-480.

47. Verhey, K. J., D. Meyer, R. Deehan, J. Blenis, B. J. Schnapp, T. A. Rapoport, and B. Margolis. 2001. Cargo of kinesin identified as JIP scaffolding proteins and associated signaling molecules. J. Cell Biol. 152, 959-970.

48. Warita, H., Y. Itoyama, and K. Abe. 1999. Selective impairment of fast anterograde axonal transport in the peripheral nerves of asymptomatic transgenic mice with a G93A mutant SOD1 gene. Brain Res. 819, 120-131.

49. Williamson, T. L. and D. W. Cleveland. 1999. Slowing of axonal transport is a very early event in the toxicity of ALS-linked SOD1 mutants to motor neurons. Nat. Neurosci. 2, 50-56.

50. Yang, J. T., R. A. Laymon, and L. S. Goldstein. 1989. A three-domain structure of kinesin heavy chain revealed by DNA sequence and microtubule binding analyses. Cell 56, 879-889.

51. Zakharenko, S. S., J. Joseph, S. Vronskaya, D. Yin, U. K. Schubart, E. R. Kandel, and V. Y. Bolshakov. 2005. Stathmin, a gene enriched in the amygdala, controls both learned and innate fear. Cell 123, 697-709.

52. Zhao, C., J. Takita, Y. Tanaka, M. Setou, T. Nakagawa, S. Takeda, H. W. Yang, S. Terada, T. Nakata, Y. Takei, M. Saito, S. Tsuji, Y. Hayashi, and N. Hirokawa. 2001. Charcot-Marie-Tooth disease type 2A caused by mutation in a microtubule motor KIF1Bbeta. Cell 105, 587-597.

\section{초록 : Kinesin superfamily KIF1A와 결합하는 미세소관 불안정화 단백질 SCG10의 규명}

문일수 ${ }^{1} \cdot$ 석대현*

(인제대학교 의과대학 생화학교실, ${ }^{1}$ 동국대학교 의과대학 해부학교실)

미세소관은 세포골격단백질의 중요한 구성 단백질로 축삭돌기 내에서는 세포막 방향으로 정렬되어 있다. Kinesin superfamily $(\mathrm{KIFs})$ 는 세포 내에서 미세소관을 따라 세포 내 소포들을 운반하는 분자 자동차(molecular motor) 단백질이다. 본 연구에서 우리는 효모 two-hybrid system을 사용하여 KIF1A의 coiled-coil 영역과 결합하는 단백질로 미세소관 불안정화 요소인 SCG10단백질을 분리하였다. SCG10은 KIFs에서 KIF1A와만 특이적으로 결합 하며, KIF1A의 400에서 820 아미노산 부위가 SCG10과의 결합에 필수적임을 효모 two-hybrid assay로 확인하였다. 또한 SCG10의 coiled-coil 영역은 KIF1A와의 결합에 필수영역임을 확인하였으며 단백질간의 결합은 Glutathione $S$-transferase pull-down assay를 통하여 확인하였다. 생쥐의 뇌 파쇄액에 SCG10 항체로 면역침강을 행하여 KIF1A 를 확인한 결과 KIF1A는 SCG10과 특이적으로 같이 침강하였다. 이러한 결과들은 KIF1A는 SCG10와 결합하여 SCG10이 포함된 소포를 미세소관을 따라 이동시킴을 시사한다. 